\title{
Effects of resveratrol on Th17 cell-related immune responses under tacrolimus-based immunosuppression
}

\author{
Kyoung Chan Doh ${ }^{1,2}$, Bo-Mi Kim ${ }^{1,2}$, Kyoung Woon Kim ${ }^{1,2}$, Byung Ha Chung ${ }^{1,2,3}$ and Chul Woo Yang ${ }^{1,2,3^{*}}$ (D)
}

\begin{abstract}
Background: We previously reported that tacrolimus (Tac) does not decrease T helper 17 cells (Th17) response in kidney transplantation. In this study, we evaluated whether Resveratrol (Resv) has immunosuppressive effects by decreasing Th17 responses in Tac-based immunosuppression.

Methods: We investigated the effects of Resv under Tac-treatment conditions, on $\mathrm{CD}^{+} \mathrm{T}$ cell differentiation to Th17 cells in peripheral blood mononuclear cells (PBMCs), and proliferation of CD4 ${ }^{+} \mathrm{T}$ cells co-cultured with human renal proximal tubular epithelial cells (HRPTEpiCs). The effects of Resv on Th17 cells were tested in the murine skin transplant model.

Results: In PBMCs, Tac did not but combination of Tac and Resv further suppressed Th17 immune response. In the co-culture study, combination of Resv to Tac significantly decreased HRPTEpiC-induced T cell proliferation compared to Tac alone. Resv treatment in the Jurkat cell induced the expression of AMP-activated protein kinase and suppressed the expression of mammalian target of rapamycin (mTOR), suggesting blocking Th17 pathway by Resv. In the murine skin transplant model, combination of Resv to Tac significantly prolonged skin graft survival accompanied by the suppression of Th17 cells, compared to either the Tac-alone or control groups.

Conclusion: The results of our study suggest that Resv provides additional immunosuppressive effects to Tac by suppressing effector $\mathrm{CD}^{+} \mathrm{T}$ cells, especially Th17 cells, in the transplantation setting.
\end{abstract}

Keywords: Th17 cells, Resveratrol, Tacrolimus, AMPK, mTOR, Organ transplantation

\section{Background}

Most cases of allograft rejection in solid organ transplantation (SOT) develop through the activation of allo-immune responses induced by effector $\mathrm{CD} 4^{+} \mathrm{T}$ cells. [1] Out of various $\mathrm{CD} 4^{+} \mathrm{T}$ cell subsets, the activation of Th1 and Th17 cells has most commonly been reported to be associated with the development of allograft rejection in SOT, [2-5] and we also reported that Th17 cells and their associated cytokines play a significant role in the development of acute and chronic allograft rejection. [1, 4-10]

Immune suppressants currently in use mainly take effect by down-regulating the proliferation or differentiation of $\mathrm{T}$

\footnotetext{
*Correspondence: yangch@catholic.ac.kr

${ }^{1}$ Convergent Research Consortium for Immunologic disease, St. Mary's Hospital, The Catholic University of Korea, Seoul, South Korea

${ }^{2}$ Transplant research center, St. Mary's Hospital, The Catholic University of

Korea, Seoul, South Korea

Full list of author information is available at the end of the article
}

cells, $[7,11]$ and tacrolimus (Tac) is a promising immunosuppressant in regulating $\mathrm{T}$ cell responses. Until now, the effect of Tac on regulation of Th17 derived immune cells has been controversial. Previous reports have shown that Tac effectively suppressed Th17 immune responses in experimental models of airway inflammation, osteoclastogenesis and psoriasis, [12-14] but the suppressive effects Tac on Th17 immune responses in kidney transplantation were shown to be somewhat inadequate. $[15,16]$ Therefore, if a substance that effectively inhibits Th17 immune responses is administered together with Tac the desired immunosuppressive effect may be expected.

In this study, we chose Resveratrol (Resv) as a regulator for Th17 immune responses, combined with Tac. Resv is a natural polyphenol compound and its therapeutic effects have been reported in metabolic disorders, such as diabetic nephropathy. [17] Recent studies have 
revealed its immune modulating effects in various immune diseases that primarily depend on Th17 immune responses. [18-20] It is also effective modulator of mammalian target of rapamycin (mTOR) signaling, which plays an important role in the regulation of Th17 cell differentiation. [21]

The aim of this study is to investigate the effect of Resv on Th17 immune responses when added to Tac. To this end, we performed an in vitro study using $\mathrm{CD} 4^{+} \mathrm{T}$ cells isolated from peripheral blood mononuclear cells (PBMCs) of healthy volunteers, and human renal proximal tubular epithelial cells (HRPTEpiCs) An in vivo study using a skin allograft mouse model was also carried out.

\section{Methods}

\section{In vitro and in vivo study design}

We designed three separate in vitro experiments and an in vivo study. First, we evaluated the suppressive effects of Resv on the differentiation of $\mathrm{CD}^{+} \mathrm{T}$ cells into Th1 $\left(\mathrm{CD} 4^{+} \mathrm{IFN}-\gamma^{+}\right)$, Th2 $\left(\mathrm{CD} 4^{+} \mathrm{IL}_{-} 4^{+}\right)$, Th17 $\left(\mathrm{CD} 4^{+} \mathrm{IL}_{-1} 7^{+}\right)$, and Treg $\left(\mathrm{CD}^{+} \mathrm{CD}^{+} 5^{+} \mathrm{FOXP3}^{+}\right)$cells out of the total $\mathrm{CD}^{+}{ }^{+} \mathrm{T}$ cell population using Th0 polarizing conditions and on the differentiation of Th17 cells using Th17 specific polarizing conditions under a Tac present condition using PBMCs isolated from 6 healthy individuals aged $27-40$ years. Second, we performed flow cytometry analysis to investigate the suppressive effects of Resv on the proliferation of T cells which were cultured under Th17 polarizing conditions and thereafter activated in a co-culture system with HRPTEpiCs under Tac with or without Resv. Third, we investigated the pathways involved in the suppressive effects of Resv on Th17 cell activation using the Jurkat cell line. Lastly, we conducted an in vivo study using a murine skin transplant model to investigate the suppressive effects of Resv on Th1 and Th17 cells, and to identify the protective effects of Resv against allograft rejection under Tac treatment.

\section{Isolation and purification of $\mathrm{CD4}^{+} T$ from PBMCs of healthy volunteers}

PBMCs were isolated from heparinized blood of healthy volunteers using Ficoll-Hypaque density-gradient centrifugation (GE Healthcare; PA, USA). The isolated cells were cultured as previously described. [22] In brief, a cell suspension of $1 \times 10^{6}$ cells $/ \mathrm{mL}$ was prepared in RPMI1640 medium supplemented with $10 \%$ fetal calf serum (FCS), $100 \mathrm{U} / \mathrm{mL}$ penicillin, $100 \mathrm{mg} / \mathrm{mL}$ streptomycin, and $2 \mathrm{mML}$-glutamine. $\mathrm{CD} 4^{+} \mathrm{T}$ cells were isolated from the PBMCs using monoclonal anti-human-CD4 antibodies conjugated to microbeads (MicroBeads; Miltenyi Biotech, Bergisch Gladbach, Germany). For cytokine detection at the single-cell level, PBMCs were stimulated with $50 \mathrm{ng} / \mathrm{mL}$ phorbol myristate acetate
(PMA) (BD Biosciences, San Diego, CA, USA) and $1 \mu \mathrm{g} / \mathrm{mL}$ ionomycin (Sigma, St. Louis, Mo, USA) in the presence of GolgiStop (BD Biosciences, San Diego, CA, USA) for $4 \mathrm{~h}$.

\section{Induction of $\mathrm{CD}^{+} T$ cell differentiation using Th0 polarizing condition in vitro}

Isolated PBMCs cells $\left(5 \times 10^{5}\right)$ from healthy people were incubated under appropriate conditions for $48 \mathrm{~h}$. To induce $\mathrm{CD} 4^{+} \mathrm{T}$ cell differentiation (Th0 polarizing condition), $[15,16,23]$ PBMCs were incubated with anti-CD3 $(1 \mu \mathrm{g} / \mathrm{mL})$ (BD Biosciences, San Diego, CA, USA) and anti-CD28 $(1 \mu \mathrm{g} / \mathrm{mL})$ (BD Biosciences, San Diego, CA, USA). To examine the immunosuppressive effects of Tac (Astellas Pharma Ltd) and Resv (Sigma, St. Louis, Mo, USA), PBMCs were pre-incubated for $1 \mathrm{~h}$ with Tac (1, $10 \mathrm{ng} / \mathrm{mL})$ with or without Resv $(25,50 \mathrm{uM})$, and then stimulated as described above. We compared the differentiation of the T cell subset (Th1, Th17, Th2 and Treg) in nil, Tac $(1,10 \mathrm{ng} / \mathrm{mL})$, and Tac $(1 \mathrm{ng} / \mathrm{mL})$ plus Resv $(25,50 \mathrm{uM})$ conditions using flow cytometry. We also compared cytokine levels (IL-2, IFN- $\gamma$, and IL-17) using ELISA in the cell culture supernatant and the expression of mRNA (IFN- $\gamma$, and IL-17) using real-time PCR.

\section{Induction of Th17 cell differentiation using Th17 polarizing conditions in vitro}

Isolated PBMCs cells $\left(5 \times 10^{5}\right)$ from healthy people were incubated under appropriate conditions for $48 \mathrm{~h}$. To induce Th17 differentiation (Th17 polarizing condition), $[15,16]$ PBMCs $\left(5 \times 10^{5}\right)$ were incubated for $48 \mathrm{~h}$ with anti-CD3 $(1 \mu \mathrm{g} / \mathrm{mL})$ (BD Biosciences, San Diego, CA, USA), anti-CD28 (1 $\mu \mathrm{g} / \mathrm{mL})$ (BD Biosciences, San Diego, CA, USA), IL-1 $\beta$ (20 ng/mL) (R\&D Systems, Inc. Minneapolis, MN, USA), IL-6 (20 ng/mL) (R\&D Systems, Inc. Minneapolis, MN, USA), IL-23 (20 ng/mL) (R\&D Systems, Inc. Minneapolis, MN, USA), and interferon-gamma (IFN- $\gamma)$-neutralizing antibody $(2 \mu \mathrm{g} /$ $\mathrm{mL}$ ) (R\&D Systems, Inc. Minneapolis, MN, USA) and IL-4-neutralizing antibody $(2 \mu \mathrm{g} / \mathrm{mL})$ (R\&D Systems, Inc. Minneapolis, MN, USA). To examine the immunosuppressive effects of Tac (Tacrobell ${ }^{\circ}$, Chong Kun Dang Pharma, Seoul, Korea) and Resv (Sigma, St. Louis, Mo, USA), PBMCs were pre-incubated for $1 \mathrm{~h}$ with Tac (1, $10 \mathrm{ng} / \mathrm{mL})$ with or without Resv $(25,50 \mathrm{uM})$, and then stimulated as described above. We compared the differentiation of the Th17 cells in nil, Tac $(1,10 \mathrm{ng} / \mathrm{mL})$, and Tac $(1 \mathrm{ng} / \mathrm{mL})$ plus Resv $(25,50 \mathrm{uM})$ conditions using flow cytometry. We also compared Th17 associated cytokine levels (IL-17, and IL-22) using ELISA in the culture supernatant and the expression of mRNA (IL-17, IL-22) using real-time PCR. 


\section{Human renal proximal tubular epithelial cells (HRPTEpiCs) and Jurkat cells}

HRPTEpiCs were purchased from ScienCell Research Laboratories (ScienCell, San Diego, CA, USA). HRPTEpiCs were maintained in epithelial cell medium (EpiCM, ScienCell, San Diego, CA, USA) supplemented with $2 \%$ fetal bovine serum (FBS) at $37^{\circ} \mathrm{C}$ with $5 \% \mathrm{CO}_{2}$. The Jurkat cell lines (ATCC TIB-152, Manassas, VA, USA) were maintained in RPMI 1640 (Gibco Life Technologies, NY, USA) supplemented with $10 \% \mathrm{FBS}$ at $37^{\circ} \mathrm{C}$ with $5 \% \mathrm{CO}_{2}$.

\section{PKH-67 labeling of isolated $C D 4^{+} T$ cells and co-culture with HRPTEpiCs}

All reagents and buffers were at room temperature before starting the PKH-67 labeling step. PKH 67 (Sigma/ Aldrich Chemical Company, St. Louis, MO, USA) was diluted according to the manufacturer's kit directions. PBMCs $\left(3 \times 10^{6}\right)$ were incubated for $48 \mathrm{~h}$ under Th17 polarizing conditions as described previously, and then were washed in Dulbecco's PBS (Gibco/BRL, Grand Island, NY, USA), and were re-suspended in $1 \mathrm{~mL}$ of solution $\mathrm{C}$ from the kit. The PKH-67 was diluted to $4 \times 10^{-}$ ${ }^{6} \mathrm{M}$ in $1 \mathrm{~mL}$ of solution $\mathrm{C}$. The cells were combined with dye, and the tube was inverted several times over 3 mins. About $2 \mathrm{~mL}$ of FCS was added to the tube, and it was inverted continuously for $1 \mathrm{~min}$. The cells were then transferred to a $15-\mathrm{mL}$ conical tube with $4 \mathrm{~mL}$ of RPMI 1640 without Phenol Red (Sigma/Aldrich Chemical Company, St. Louis, MO, USA), and with 10\% FCS (BioWhittaker, Walkersville, MD, USA) and washed three times in the same medium. To examine the immunosuppressive effects of Resv, PKH-67 labeled $\mathrm{CD}^{+}{ }^{+} \mathrm{T}$ cells were co-cultured with HRPTEpiCs at a ratio of 150,000:20,000 [24] with/without Resv (25, $50 \mathrm{uM}$ ) or Tac $(1,10 \mathrm{ng} / \mathrm{mL})$. After 3 days, the harvested cells were examined for proliferation using a FACS Caliber flow cytometer (BD Biosciences, San Diego, CA, USA).

\section{Flow cytometry analysis}

The cells were surface-stained with CD4-PE/Cy7 (RPA-T4, IgG1; BioLegend, San Diego, CA, USA), and To stain intracellularly, the cells were washed, fixed, permeabilized, and incubated with mAbs against IL-17 (PE, eBio64dec17, IgG1, к; eBioscience, San Diego, CA, USA), IFN- $\gamma$ (FITC, 4S.B3, IgG1, $\kappa$; eBioscience, San Diego, CA, USA; and PE, B27, IgG1, א; Pharmingen, San Diego, CA, USA), IL-4 (APC, MP4-25D2, IgG1, א; eBioscience, San Diego, CA, USA), and Foxp3 (FITC, PCH101, IgG2a, K; eBioscience, San Diego, CA, USA). The appropriate isotype controls were used for gating purposes. The cells were analyzed using a FACS Calibur flow cytometer (BD Biosciences, San Diego, CA, USA), and the data were analyzed using the FlowJo software (Tree Star, Ashland, OR, USA).

\section{Enzyme-linked immunosorbent assay (ELISA)}

IL-2, IFN- $\gamma$, IL-17, and IL-22, in the culture supernatants of $\mathrm{CD}^{+} \mathrm{T}$ cells were measured using sandwich ELISA (R\&D Systems, Inc. Minneapolis, MN, USA), according to the manufacturer's instructions. The absorbance at $405 \mathrm{~nm}$ was measured using an ELISA microplate reader (Molecular Devices).

\section{Real-time reverse transcription polymerase chain reaction} mRNA was extracted from $\mathrm{CD}_{4}^{+} \mathrm{T}$ cells using the TRIzol Reagent (Molecular Research Center, Inc., Cincinnati, OH, USA), according to the manufacturer's instructions. cDNA was synthesized in a PerkinElmer Cetus DNA thermal cycler (PerkinElmer, Inc., Waltham, MA, USA) using the SuperScript Reverse Transcription system (Takara). A LightCycler 2.0 instrument (Roche Diagnostics; software version 4.0) was used for PCR amplification, and all PCR reactions were performed using LightCycler FastStartDNA Master SYBR Green I (Takara) according to the manufacturer's instructions. The following primers were used for each molecule: IL-21, 5' TTC TGC CAG CTC CAG AAG AT 3'(sense) and 5' TTG TGG AAG GTG GTT TCC TC 3'(antisense); for IFN- $\gamma 5^{\prime}$ TCC CAT GGG TTG TGT GTT TA 3'(sense) and 5' AAG CAC CAG GCA TGA AAT CT 3' (antisense); for IL-17, 5' CAA CCG ATC CAC CTC ACC TT 3'(sense) and 5' GGC ACT TTG CCT CCC AGAT 3'(antisense); and for $\beta$-actin, 5' GGA CTT CGA GCA AGA GAT GG 3'(sense) and 5' TGT GTT GGG GTA CAG GTC TTTG 3'(antisense). Housekeeping genes ( $\beta$-actin) were amplified for normalization.

\section{Western blot analysis}

Jurkat cell lines were pre-incubated for $3 \mathrm{~h}$ in the presence of Resv or Tac and then stimulated under Th17 specific polarizing conditions for another $1 \mathrm{~h}$. The membrane was then incubated overnight at $4{ }^{\circ} \mathrm{C}$ with primary antibodies against the following: phosphorylated AMPK (p-AMPK), AMPK, phosphorylated mTOR (p-mTOR), mTOR, (all antibodies were from Cell Signaling Technology Inc., Danvers, MA, USA), and $\beta$-actin (Sigma, St. Louis, Mo, USA). After washing in TTBS, the reactive bands were visualized using an ECL detection kit and Hyperfilm-ECL reagents (Amersham Pharmacia, Piscataway, NJ, USA).

\section{In vivo experiment using skin allograft mice model Animals and drugs}

All animal experiments were performed in accordance with the Laboratory Animals Welfare Act, the Guide for the Care and Use of Laboratory Animals, and were approved by the Institutional Animal Care and Use Committee at College of Medicine, the Catholic University of Korea (CUMC-2015 - 0057-02). 
Eight-week-old male mice weighing 25-30 g (Taconic Anmed, Rockwille, MD, USA) were housed in individual cages in a temperature and light-controlled environment. Tacrolimus (Tacrobell ${ }^{\circ}$, Chong Kun Dang Pharma, Seoul, Korea) was diluted in sterile, distilled water to a final concentration of $2 \mathrm{mg} / \mathrm{mL}$. Drug administration started 3 days before skin allograft transplantation. Resveratrol (Sigma, St. Louis, Mo, USA) was dissolved with $0.5 \%$ carboxymethyl cellulose sodium salt (CMC). We collected the mouse skin and blood under general anesthesia with $10 \mathrm{mg} / \mathrm{kg}$ xylazine hydrochloride (Rompun; Bayer, Leuverkusen, Germany) and $30 \mathrm{mg} / \mathrm{kg}$ tiletamine plus zolazepam (Zoletil; Virbac, Carros, France). After which mice were sacrificed by asphyxiation using compressed $\mathrm{CO}_{2}$ and chamber.

\section{Experimental design}

Mice were randomized into three groups, with six animals per group, as follows:

1. Vehicle (VH) group: Daily oral administration of water for 2 weeks.

2. Tac $2 \mathrm{mg} / \mathrm{kg}$ group: Daily oral administration of Tac $2 \mathrm{mg} / \mathrm{kg}$ for 2 weeks.

3. Tac $2 \mathrm{mg} / \mathrm{kg}$ and Resv $100 \mathrm{mg} / \mathrm{kg}$ group: Daily oral administration of Tac $2 \mathrm{mg} / \mathrm{kg}$ and Resv $100 \mathrm{mg} / \mathrm{kg}$ for 2 weeks.

\section{Skin allograft operation procedure}

Skin allograft operation was carried out as previously described. [25] Briefly, adult male BALB/C (H-2 $\left.{ }^{\mathrm{d}}\right)$ and C57BL/6 $\left(\mathrm{H}-2^{\mathrm{b}}\right)$ mice were used for skin transplantation. Donor and recipients were anesthetized with an intraperitoneal injection. Tail skin of C57BL/6 mice, segmented into $1 \times 1 \mathrm{~cm}^{2}$ pieces were used to replace previously removed BALB/c mouse back skin. The skin graft was sutured with six stitches and was covered with gauze and fixed with a bandage. The bandage was removed on day three, postoperative. From this day, photographs were taken daily with a camera. [26]

\section{Ex vivo flow cytometry using isolated mice spleen}

At day 6 after skin grafting, single-cell suspensions of the spleens of mice were prepared and stained with fluorescently labeled monoclonal antibodies. Splenocytes were stained with various combinations of fluorochrome conjugated antibodies against CD4 (PerCP-Cyanine5.5, IgG2a K; eBioscience, San Diego, CA, USA). For intracellular staining, the cells were washed, fixed, permeabilized, and incubated with mAbs against IL-17-FITC, and IFN- $\gamma$-PE (all from IgG1, $\kappa$; eBioscience, San Diego, CA, USA). The cells were analyzed using a FACS Calibur flow cytometer (BD Biosciences, San Diego, CA,
USA). The data were analyzed using the FlowJo software (Tree Star, Ashland, OR, USA).

\section{Histology}

The transplanted skin graft was removed at 6 days post-transplant in 1 mouse from each group. The skin grafts were fixed in $10 \%$ buffered formalin, and tissues were then embedded in paraffin. 4- $\mu \mathrm{m}$ tissue sections were stained with hematoxylin-eosin (H\&E) (Sigma, St. Louis, Mo, USA) to assess cellular infiltration.

\section{Statistical analysis}

Statistical analysis was conducted using the SPSS software (version 16.0; SPSS Inc., Chicago, IL, USA). Continuous variables were summarized as mean $\pm \mathrm{SD}$. A non-parametric Wilcoxon signed-rank test was used to compare $\mathrm{T}$ cell suppression, cytokine production, and gene expression between the control and treatment groups. Skin allograft survival was compared using the Kaplan-Meier method and Log-rank test. A $p$ value of $<0.05$ was considered to be statistically significant.

\section{Results}

The suppressive effects of Resv on the differentiation of $\mathrm{CD}^{+} \mathrm{T}$ cells into effector $\mathrm{T}$ cells

The proportions of Th1, Th2, Th17, and Treg cells to the total $\mathrm{CD}^{+} \mathrm{T}$ cell population in each condition are presented in Fig. 1a. Tac significantly reduced the proportion of Th1 cells in comparison to cells under Th0 polarizing conditions, in a dose dependent manner $(P<0.05$ for both). Combination of Resv $(25,50 \mu \mathrm{M})$ to Tac $(1 \mathrm{ng} / \mathrm{mL})$ also showed significant suppressive effects on Th1 cells compared to cells under Th0 polarizing conditions ( $\mathrm{P}<0.05$ for both) (Fig. 1b). The combination of Resv $50 \mu \mathrm{M}$ to Tac $1 \mathrm{ng} / \mathrm{mL}$, especially displayed stronger significant suppressive effects than the Tac 1 $\mathrm{ng} / \mathrm{mL}$ alone condition $(P<0.05)$. Treatment with Tac $(1,10 \mathrm{ng} / \mathrm{mL})$ resulted in a decreasing tendency of the proportion of Th2 cells. In contrast, combination of Resv (both 25 and $50 \mu \mathrm{M})$ to Tac $(1 \mathrm{ng} / \mathrm{mL})$ resulted in a significant increase of the proportion of Th2 cells compared to the Th0 polarizing condition and Tac treatment condition $(P<0.05$ for all) (Fig. 1c). Treatment with Tac $(1 \mathrm{ng} / \mathrm{mL})$ did not suppress Th17 cells in comparison to the Th0 polarizing condition. Combination of Resv (both 25 and $50 \mu \mathrm{M})$ to Tac $(1 \mathrm{ng} / \mathrm{mL})$, however, resulted in a significant reduction of the proportion of Th17 cells compared to the Th0 polarizing condition alone, in a dose dependent manner ( $\mathrm{P}<0.05$ for both) (Fig. 1d). In regard to Treg cells, Tac significantly decreased the proportion of Treg cells in comparison to the Th0 polarizing condition, and combination of Resv to Tac did not change the proportion of Treg cells (Fig. 1e). 

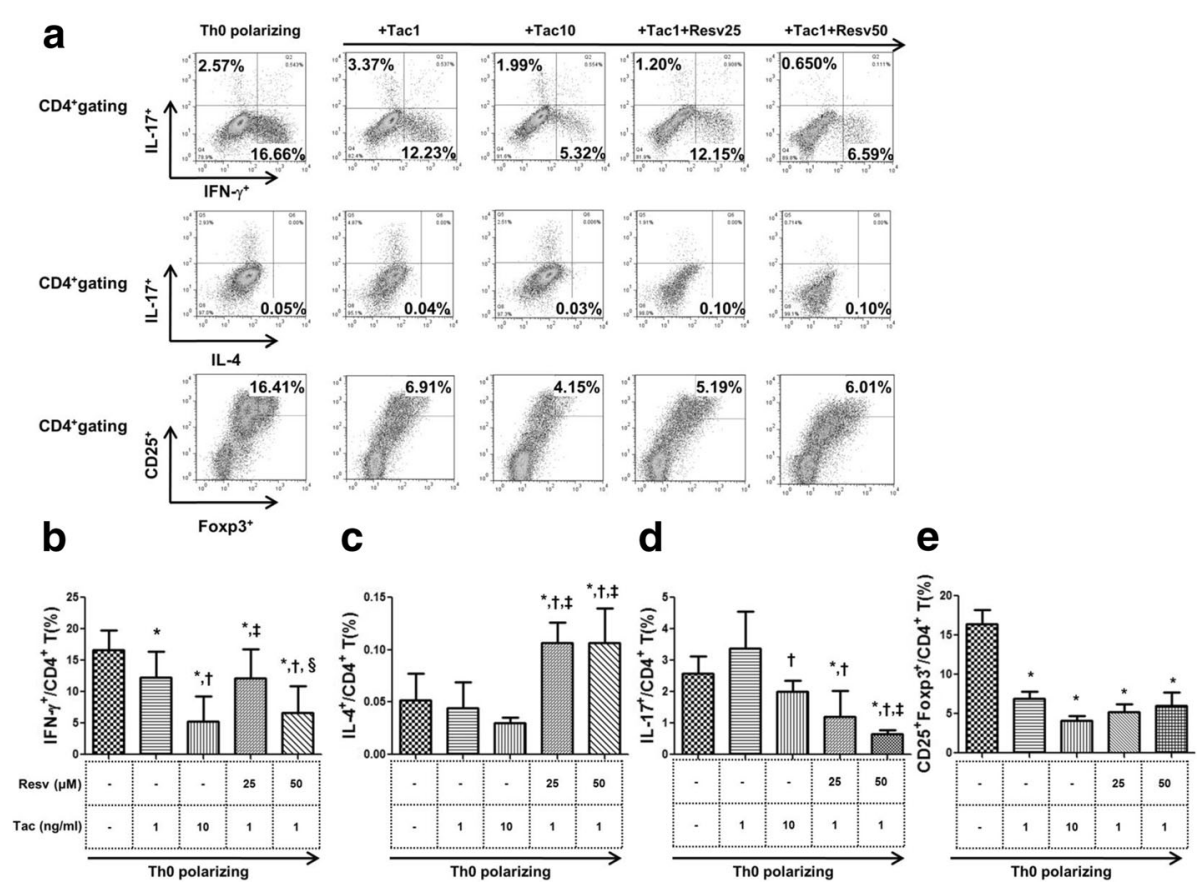

Fig. 1 The suppressive effects of Resv on the differentiation of CD4 ${ }^{+} T$ cells into effector $T$ cells. (a) Representative figure of flow cytometry using CD4 ${ }^{+} T$ stained with anti-IFN- $\gamma$ FITC, anti-IL-17 PE and anti-IL-4 APC. The effect of Tac with or without Resv on (b) Th1 (IFN- $\gamma^{+} / C D 4^{+} T$ cells), (c) Th2

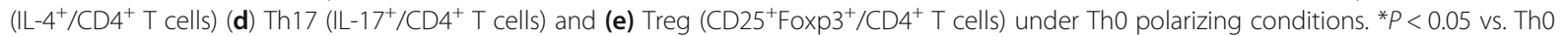
polarizing ${ }^{\dagger} \mathrm{P}<0.05$ vs. Tac $1 \mathrm{ng} / \mathrm{mL}$ group ${ }^{\ddagger} \mathrm{P}<0.05$ vs. Tac $10 \mathrm{ng} / \mathrm{mL}$ group $\S \mathrm{P}<0.05$ vs. Tac $1 \mathrm{ng} / \mathrm{mL}+$ Resv $25 \mu \mathrm{M}$ group. Resv, Resveratrol; Tac, tacrolimus; Treg, regulatory $T$ cells

The suppressive effects of Resv on inflammatory cytokine production from isolated $\mathrm{CD}^{+}{ }^{+} \mathrm{T}$ cells

Tac $(1,10 \mathrm{ng} / \mathrm{mL})$ suppressed IL-2 levels to a greater extent than the Th0 polarizing conditions in a dose dependent manner ( $p<0.05$ for both). Combination of $\operatorname{Resv}(25,50 \mu \mathrm{M})$ to Tac $(1 \mathrm{ng} / \mathrm{mL})$ also showed significant suppressive effects on the level of IL-2 in a dose dependent manner $(p<0.05$ for both vs. the Th0 polarizing condition) and combination of Resv $(50 \mu \mathrm{M})$ to Tac $(1 \mathrm{ng} / \mathrm{mL})$ showed even more significant suppressive effects than the Tac $(1 \mathrm{ng} / \mathrm{mL})$ alone condition. (Fig. 2a) Tac $(1,10 \mathrm{ng} / \mathrm{mL})$ suppressed IFN- $\gamma$ levels to a greater extent than the Th0 polarizing condition ( $p<0.05$ for both) and combination of $\operatorname{Resv}(25,50 \mu \mathrm{M})$ to $\mathrm{Tac}(1 \mathrm{ng} / \mathrm{mL})$ also significantly decreased IFN- $\gamma$ level compared to the Th0 polarizing condition or Tac $1 \mathrm{ng} / \mathrm{mL}$ alone condition $(p<0.05$ for all) (Fig. 2b). Both doses of Tac $(1,10 \mathrm{ng} / \mathrm{mL})$ did not decrease the level of IL-17, but combination of $\operatorname{Resv}(25,50 \mu \mathrm{M})$ to Tac $(1 \mathrm{ng} / \mathrm{mL})$ significantly decreased IL-17 compared to the Th0 polarizing condition in a dose dependent manner ( $p<0.05$ for both) (Fig. 2c). In all treatment conditions (Tac alone and Tac plus Resv), the mRNA expression of IFN- $\gamma$ decreased significantly compared to Th0 polarizing conditions and Resv $(50 \mu \mathrm{M})$ plus Tac $(1 \mathrm{ng} / \mathrm{mL})$ showed particularly more significant suppressive effects than with Tac $(1 \mathrm{ng} / \mathrm{mL})$ alone (Fig. $2 \mathrm{~d}$ ).
The expression of IL-17 mRNA was not significantly suppressed by Tac alone. But, the combination of Resv (25, $50 \mu \mathrm{M}+$ Tac $1 \mathrm{ng} / \mathrm{mL}$ ) significantly suppressed the expression of IL-17 mRNA compared to the Th0 polarizing condition $(P<0.05$ for all) (Fig. $2 \mathrm{e})$.

The suppressive effects of Resv on the differentiation of Th17 cells under Th17 specific polarizing conditions Pre-incubation of PBMCs isolated from 6 healthy donors with Tac $(1,10 \mathrm{ng} / \mathrm{mL})$ did not suppress the proportion of Th17 cells compared to cells under Th17 polarizing conditions alone. However, the combined use of Resv $(50 \mathrm{nM})$ to Tac $(1 \mathrm{ng} / \mathrm{mL})$ resulted in a significant reduction of Th17 cell proportions compared to Th17 polarizing conditions, and Tac 1 or $10 \mathrm{ng} / \mathrm{mL}$ conditions $(P<0.05$ for all $)$ (Fig. 3b). Combination of Resv $(50 \mu \mathrm{M})$ to Tac $(1 \mathrm{ng} / \mathrm{mL})$ also significantly decreased IL-17 compared to the Th17 polarizing condition and Tac alone $(1,10 \mathrm{mg} / \mathrm{mL})(\mathrm{P}<0.05$ for each) (Fig. 3c). Pre-incubation with Tac (1, $10 \mathrm{ng} / \mathrm{mL})$ did not suppress IL-17 mRNA expression compared to the Th17 control, but combination of $\operatorname{Resv}(25,50 \mathrm{uM})$ to Tac ( $1 \mathrm{ng} / \mathrm{mL})$ significantly suppressed IL-17 mRNA compared to both the Th17 control and Tac alone $(1,10 \mathrm{ng} / \mathrm{mL})$ (Fig. 3d). The same was true for IL-22 protein levels and mRNA expression as well. Tac alone $(1,10 \mathrm{ng} / \mathrm{mL}) \mathrm{did}$ not affect IL-22 protein levels or expression of IL-22 
a

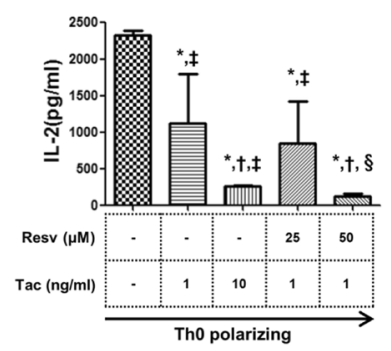

b
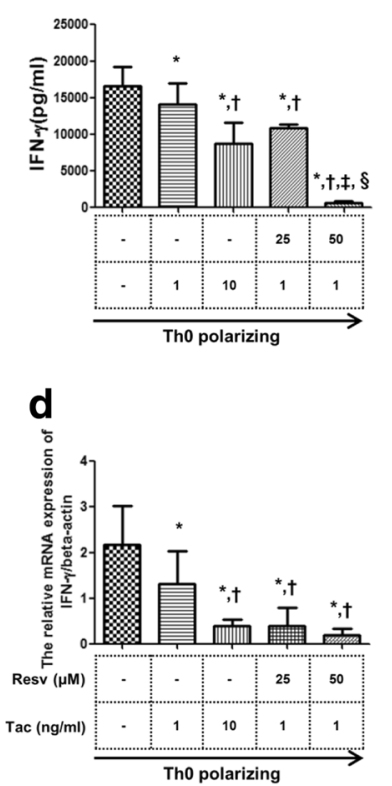

C

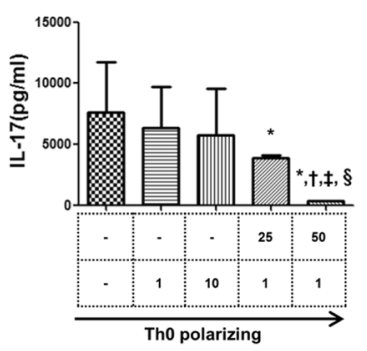

e

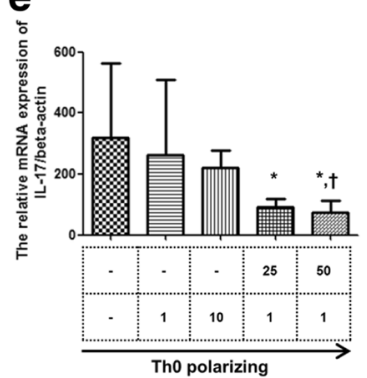

Fig. 2 The suppressive effects of Resv on inflammatory cytokine production and mRNA expression. The effects of Tac with or without Resv on the concentration of (a) IL-2 (b) IFN- $\gamma$ (c) IL-17 in the culture-supernatant and effects on the expression of (d) IFN- $-($ e) IL-17 mRNA measured using real-time $P C R$. Bars show the means ${ }^{*} P<0.05$ vs. Th0 polarizing ${ }^{\dagger} P<0.05$ vs. Tac $1 \mathrm{ng} / \mathrm{mL}$ group ${ }^{\ddagger} \mathrm{P}<0.05$ vs. Tac $10 \mathrm{ng} / \mathrm{mL} \mathrm{group}{ }^{\S} \mathrm{P}<0.05$ vs. Tac $1 \mathrm{ng} / \mathrm{mL}+$ Resv $25 \mu \mathrm{M}$ group. Resv, Resveratrol; Tac, tacrolimus

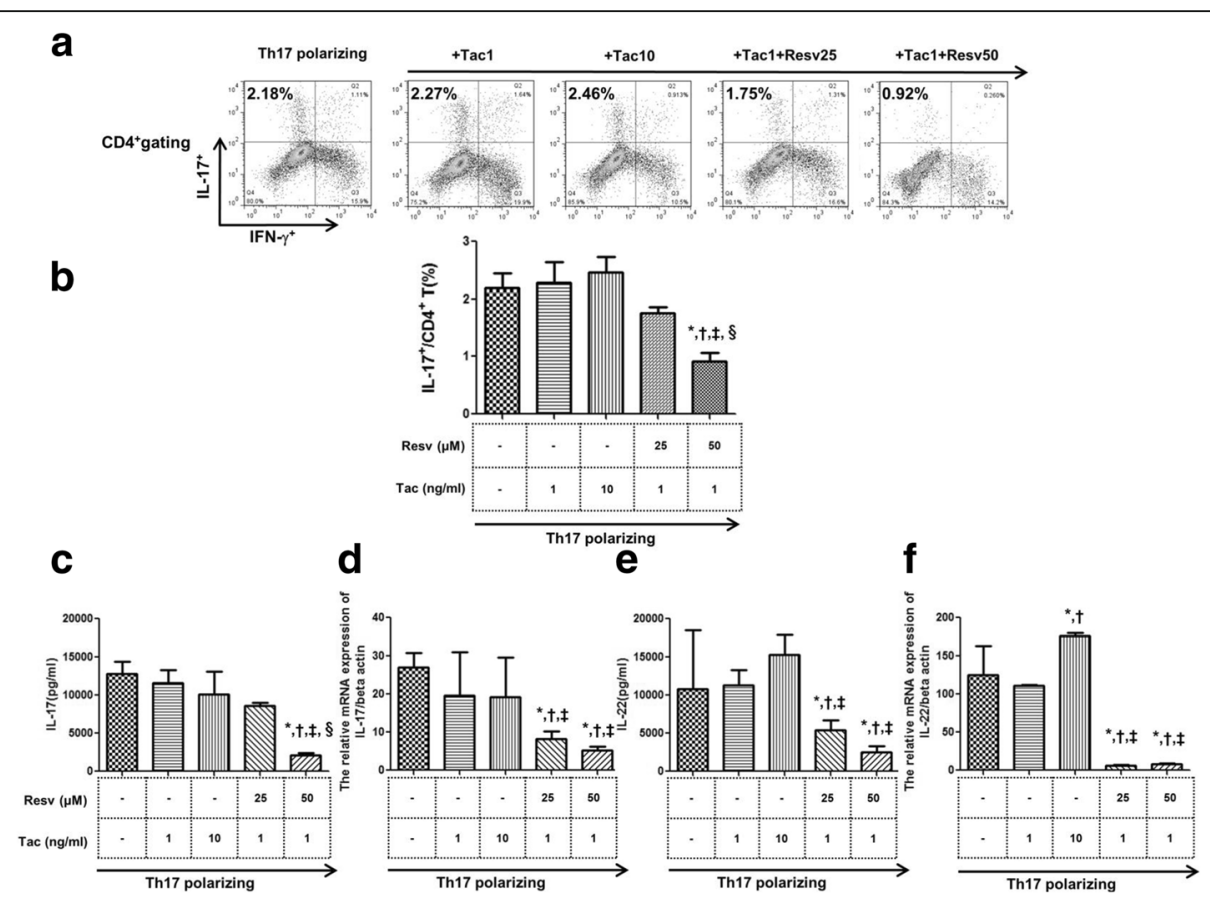

Fig. 3 The suppressive effects of Resv on the differentiation of Th17 cells under Th17 specific polarizing conditions. Effects of Tac with or without Resv on $\mathrm{CD}^{+} \mathrm{T}$ cells isolated from PBMCs of healthy donors and cultured under Th17 polarizing conditions. (a) The percentage of CD4 ${ }^{+} \mathrm{T}$ cells producing IL-17 was measured by flow cytometry. (b) The effects of Tac with or without Resv on IL-17 $7^{+} / \mathrm{CD} 4^{+} \mathrm{T}$ cells, and effects on (c) IL-17 levels (or (e) IL-22) and on the expression of (d) IL-17 (or (f) IL-22) mRNA. *P $<0.05$ vs. Th17 polarizing ${ }^{\dagger} \mathrm{P}<0.05 \mathrm{vs}$. Tac $1 \mathrm{ng} / \mathrm{mL} \mathrm{group}{ }^{\ddagger} \mathrm{P}<0.05$ vs. Tac $10 \mathrm{ng} / \mathrm{mL}$ group ${ }^{\S} \mathrm{P}<0.05 \mathrm{vs}$. Tac $1 \mathrm{ng} / \mathrm{mL}+$ Resv $25 \mu \mathrm{M}$ group. Resv, Resveratrol; Tac, tacrolimus 
mRNA compared to the Th17 polarizing condition. But combination of Resv $(25,50 \mu \mathrm{M})$ to Tac $(1 \mathrm{ng} / \mathrm{mL})$ significantly decreased IL-22 protein levels $(\mathrm{P}<0.05$ for all) and also mRNA expression of IL-22 compared to the Th17 polarizing condition or Tac alone $(1,10 \mathrm{ng} / \mathrm{mL})$ condition (Fig. 3e and f).

\section{The suppressive effects of Resv on the proliferation of $\mathrm{CD}^{+}{ }^{+} \mathrm{T}$ cells after co-culture with HRPTEpiCs}

We measured HRPTEpiC-reactive $\mathrm{CD}^{+}{ }^{+} \mathrm{T}$ cell proliferation using $\mathrm{PKH}$-labeled $\mathrm{CD}_{4}^{+} \mathrm{T}$ cells in the presence Tac, with or without Resv $(25,50 \mu \mathrm{M})$. PBMCs $\left(3 \times 10^{6}\right)$ were incubated for $48 \mathrm{~h}$ under Th17 polarizing conditions and then were co-cultured with HRPTEpiCs for 3 days. As a result, Tac (1, $10 \mathrm{ng} / \mathrm{mL}$ ) did not inhibit the proliferation of HRPTEpiC-reactive $\mathrm{CD}^{+} \mathrm{T}$ cells $\left(\mathrm{PKH}^{-} \mathrm{CD} 4^{+} \mathrm{T}\right)$ compared to the control. However, combination of Resv $(25,50 \mu \mathrm{M})$ to Tac $(1$ $\mathrm{ng} / \mathrm{mL}$ ) significantly reduced the proportion of $\mathrm{PKH}^{-} \mathrm{CD} 4^{+}$ $\mathrm{T}$ cells compared to the control and also the Tac alone condition $(1,10 \mathrm{ng} / \mathrm{mL})(p<0.05$ for all) (Fig. 4b).

The pathways involved in the suppressive effects of Resv on the differentiation of $\mathrm{CD} 4^{+} \mathrm{T}$ cells

Using the Jurkat cell line, we investigated the molecular mechanisms modulated by Resv in activated $\mathrm{CD}^{+} \mathrm{T}$ cells under Th17 polarizing conditions, especially focusing on the mTOR/AMPK signaling pathway. As shown in Fig. 5, the level of p-mTOR and p-AMPK increased significantly under the Th17 polarizing condition compared to the Nil condition $(139 \pm 14 \%$ [p-mTOR], $127 \pm$ $5 \%$ [p-AMPK] vs. 100\%, $p<0.05$ for both) (Fig. 5a). Tac $(1 \mathrm{ng} / \mathrm{mL})$ did not affect the level of both p-mTOR and p-AMPK. In contrast, Resv $(25,50 \mu \mathrm{M})$ significantly increased the level of p-AMPK in terms of relative intensity compared to the Th17 polarizing condition and also compared to the Tac alone condition $(1 \mathrm{ng} / \mathrm{mL})(p<0.05$ for each)(Fig. 5b). In addition, Resv $50 \mu \mathrm{M}$ significantly decreased the levels of p-mTOR in terms of relative intensity compared to the Th17 polarizing condition and also compared to the Tac alone condition ( $\mathrm{p}<0.05$ for each) (Fig. 5c).

The effects of Resv on allograft survival in the murine skin transplant model under tac treatment

Skin allografts in non-treatment mice were rejected with a median survival time of $5.7 \pm 0.88$ days (Fig. 6a). However, treatment with Tac $(2 \mathrm{mg} / \mathrm{kg})$ significantly prolonged the survival after skin allograft $(8.3 \pm 1.12$ days, $p<0.05$ vs. control). Interestingly, the group injected with Tac and Resv $(100 \mathrm{mg} / \mathrm{kg})$ showed greater prolongation of graft

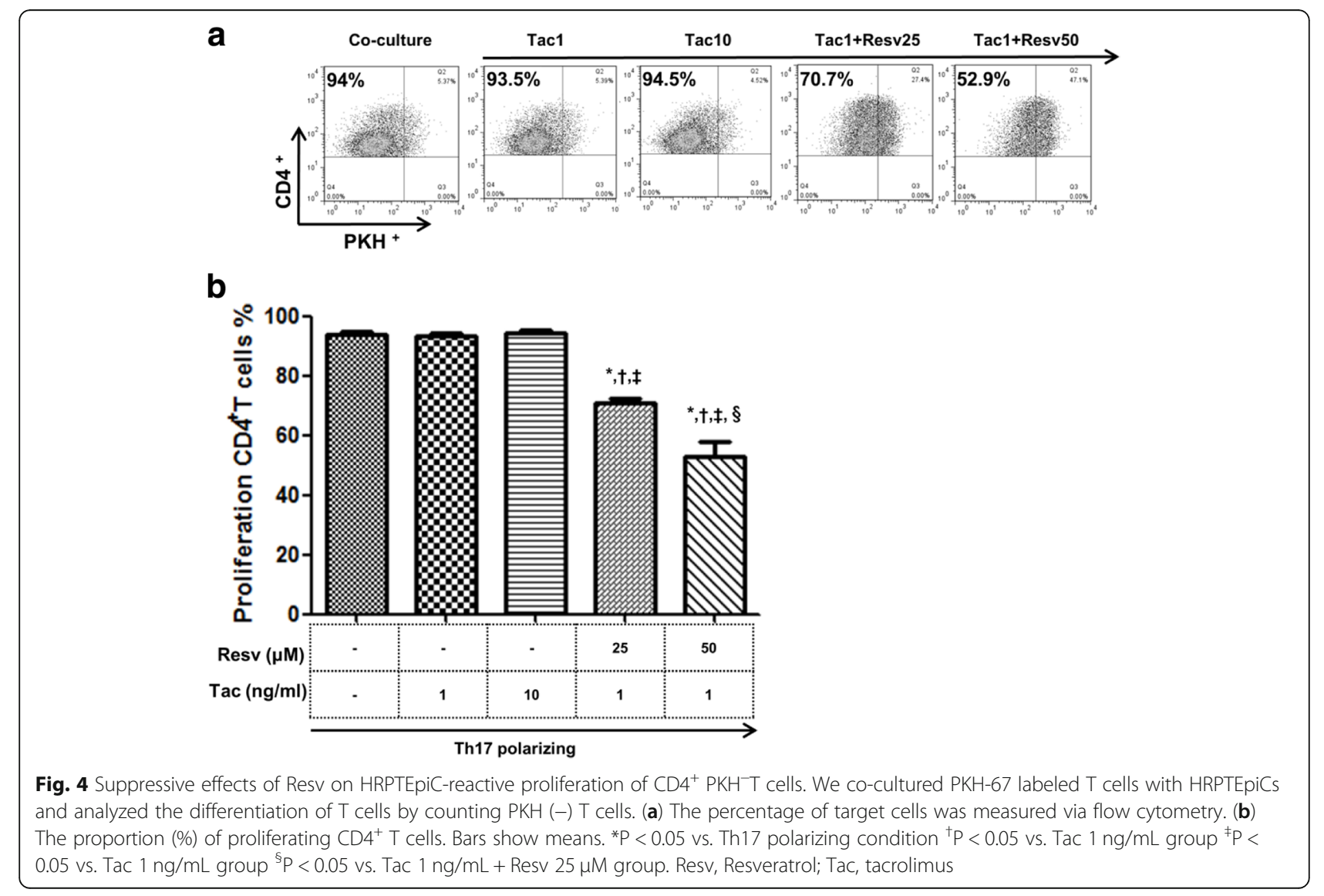



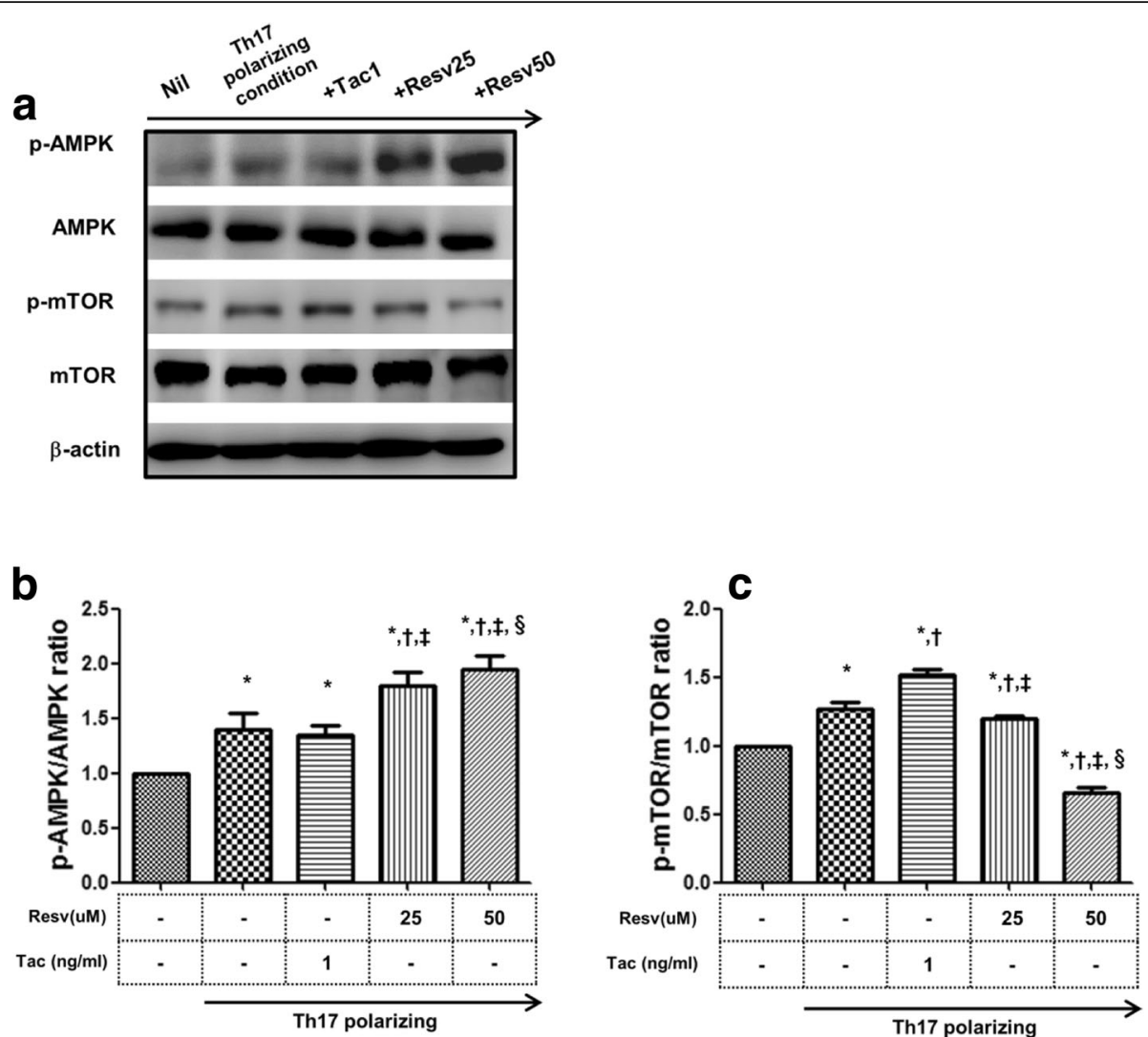

Fig. 5 Effects of Tac or Rasv on the expression of mTOR and AMPK proteins in the Jurkat cell line. (a) Immunoblotting of p-Ampk, Ampk, p$\mathrm{mTOR}_{\text {" }}$ and mTOR in the Jurkat cell line pretreated with Tac $(1 \mathrm{ng} / \mathrm{mL})$ or Resv $(25,50 \mathrm{nM})$ and then cultured under Th17-differentiation conditions. Stimulation of Jurkat cells under Th17-differentiation conditions activated phosphorylation of (b) AMPK, and (c) mTOR as detected by Western blotting and shown by the ratio of phosphorylated proteins to total proteins. Tac did not change p-AMPK or p-mTOR. In contrast, treatment with Resv resulted in the reduction of $\mathrm{p}$-mTOR and an increase in $\mathrm{p}$-AMPK. ${ }^{*} \mathrm{P}<0.05 \mathrm{vs}$. Nil and ${ }^{\mathrm{P}} \mathrm{P}<0.05$ vs. Th17 polarizing condition and ${ }^{\ddagger} \mathrm{P}<0.05$ vs. Tac $1 \mathrm{ng} / \mathrm{mL}$. Resv, Resveratrol; Tac, tacrolimus

survival compared to the control or Tac alone groups (10.3 \pm 1.36 days, $\mathrm{p}<0.05$ vs. control or Tac alone). An ex vivo analysis using mouse spleen cells isolated on day 6 after the skin graft showed that the use of Tac $(2 \mathrm{mg} / \mathrm{kg})$ resulted in a significant reduction of Th1 cells ( $\mathrm{p}<0.05 \mathrm{vs}$. control) but not in reduction of Th17 cells. Combined use of Tac and Resv significantly reduced Th1 compared to the control $(P<0.05)$ and also reduced Th17 cells in comparison with both the control and Tac alone groups $(P<$ 0.05 for both) (Fig. $6 \mathrm{~b}$ and c). Six days after transplantation, the graft was removed from the recipients for pathologic examination. The inflammatory cell infiltration of the skin allograft was significantly reduced in the Tac alone group compared to the control group, and the combined use of Tac and Resv further decreased inflammatory cell infiltration of the skin graft tissue (Fig. 6d).

\section{Discussion}

The results of our study demonstrate that combination of Resv to Tac is effective in regulating $\mathrm{CD}_{4}^{+} \mathrm{T}$ cells, including Th17 cells under Tac present conditions. An in vitro study using PBMCs and HRPTEpiCs, indicates that the combination of Resv to Tac more effectively suppressed the differentiation of Th17 cells and production of associated cytokines compared to the Tac alone condition. Furthermore, in our in vivo experiment using the murine skin transplant model, combination of Resv to Tac significantly improved skin allograft survival compared to that of the group with Tac treatment alone, with effective suppression of Th17 cells.

The effects of Tac on regulation of Th17 derived immune cells is controversial. The suppressive effects of Tac on Th17 immune responses has been reported in various experimental studies such as airway inflammation, osteoclastogenesis and psoriasis. [12-14] On the other hand, there are only a small number of animal studies on the effects of calcineurin inhibitors (CNIs) on Th17 responses in transplantation. We previously reported that Tac failed to suppress IL-17 immune responses in kidney transplantation recipients. $[15,16]$ In this study, we confirmed that Tac alone is not effective in suppressing Th17 immune response. The reason for 

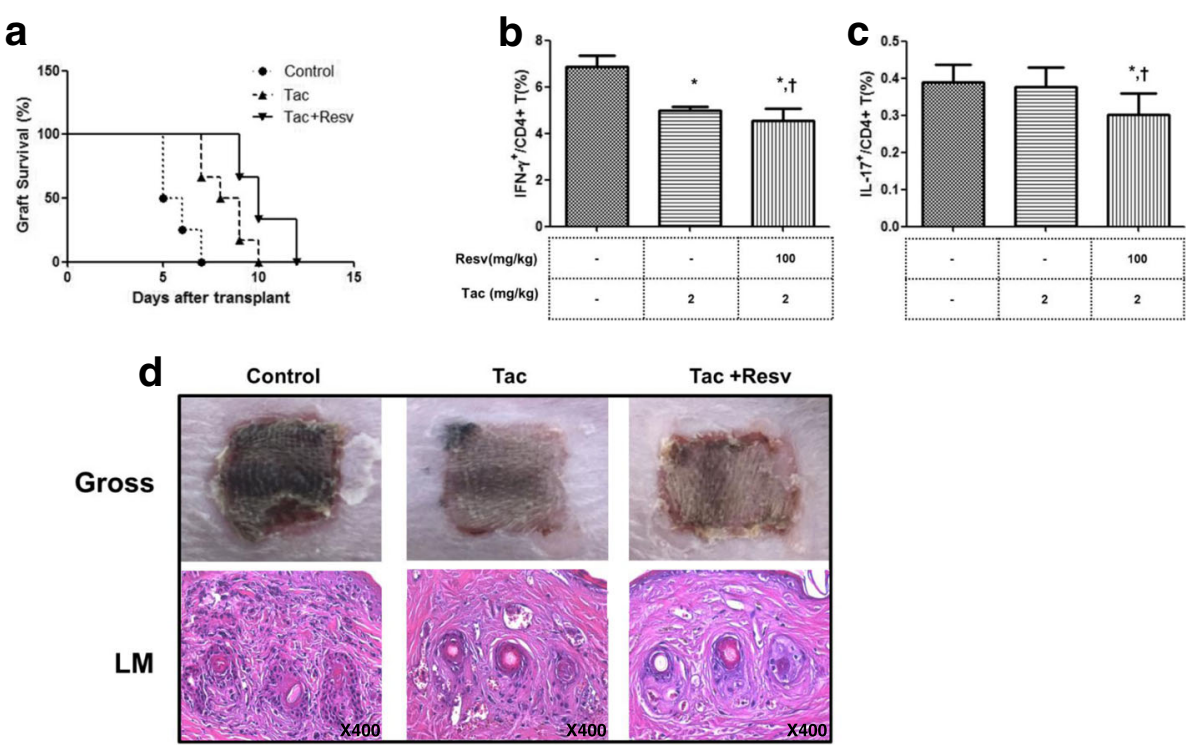

Fig. 6 Skin allograft survival in mice treated with Resv and Tac. (a) Kaplan-Meier Survival curve of skin allografts in each group with six animals per group. (b, c) The proportion (\%) of IFN- $\gamma^{+} / \mathrm{CD}^{+} \mathrm{T}$ cells, and IL-17 $/ \mathrm{CD} 4^{+} \mathrm{T}$ cells in isolated spleen cells from each group was measured via flow cytometry in six animals per group. (d) Histological changes in skin allografts at day 6 . The inflammatory cell infiltration of the skin allograft was significantly reduced in the Tac alone group compared to the control group. Combined use of Tac and Resv further decreased inflammatory cell infiltration in skin graft tissue (Magnification $\times 400$ ). ${ }^{*} \mathrm{P}<0.05$ vs Control ${ }^{\dagger} \mathrm{P}<0.05 \mathrm{vs}$. Tac $2 \mathrm{mg} / \mathrm{kg}$ group. Resv, Resveratrol; Tac, tacrolimus

this is related to the Tac dose. We used lower Tac doses $(1 \mathrm{ng} / \mathrm{ml}, 10 \mathrm{ng} / \mathrm{ml})$ compared to other experimental studies, based on a cytoxicity test. Higher doses of Tac decreased viability of PBMCs, thus, we chose Tac doses without significant cytoxicity. Furthermore, we considered therapeutic levels used in clinical practice.

First, we intended to demonstrate the effects of Resv on the differentiation of $\mathrm{CD}^{+}{ }^{+} \mathrm{T}$ cells in the presence of Tac using a well-established in vitro study model. $[16,27]$ Tac is well known to be very effective in the suppression of most effector $\mathrm{CD}^{+}{ }^{+} \mathrm{T}$ cell subsets. [28-30] However, we previously found that the effect of Tac on the Th17 is relatively limited because this drug mainly targets the Th1 pathway. $[31,32]$ As expected, in the Tac alone condition, Th1, Th2 and Treg were significantly suppressed, but effects on Th17 cells were limited. When we combination Resv to Tac, Th17 cells were significantly suppressed compared to Tac alone, which suggests compensatory effects of Resv on Tac. Meanwhile, Resv increased the proportion of Th2 cells, and these observations are consistent with those of previous studies that showed that Resv suppressed the overall differentiation of $\mathrm{T}$ cells and resulted in a shift from the Th1 to the Th2 phenotype. [33, 34] In this study, Resv failed to increase the proportion of Tregs which was decreased by Tac. The reason is unclear, but previous studies showed contradictory results in regard to the effect of Resv on Tregs. [35-37]. Another possible reason may be that Resv did not overcome the suppressive effect of Tac on Tregs, but further studies are required to clarify this issue.
We also investigated the changes in $\mathrm{T}$ cell associated cytokine levels, including IL-2, IFN- $\gamma$ and IL-17, by Tac with or without Resv using ELISA. Tac significantly suppressed IL-2, a representative T cell cytokine, as well as IFN- $\gamma$, the Th1 cytokine, but it did not decrease IL-17 levels. [38] Combination of Resv to Tac suppressed all of IL-2, IFN- $\gamma$ and also effectively suppressed IL-17 compared to the Tac alone condition as shown by our flowcytometry results. In real time PCR for mRNA expression analysis, IFN- $\gamma$ expression was significantly suppressed by Tac and further suppressed by Resv. IL-17 expression was not suppressed by Tac alone, but it was significantly suppressed by the combination of Resv to Tac. When we used Th17 polarizing conditions to focus on the effects of Resv on Th17 cells, the same was true for Th17 differentiation, Th17 cytokine and mRNA expression. Tac alone did not show significant effects on the Th17 pathway under the Th17 polarizing condition. However, combination of Resv to Tac effectively suppressed Th17 cells, levels of IL-17and IL-22 proteins and also the expression of IL-17 and IL-22 mRNA. These results are consistent with prior reports that Resv suppresses effector $\mathrm{T}$ cell differentiation and also affects $\mathrm{T}$ cell maturation by suppressing the proliferation of the inflammatory Th17 phenotype. [35]

Next, we investigated the effects of Resv on $\mathrm{CD}^{+} \mathrm{T}$ cell differentiation in an in vitro model, mimicing organ transplantation. The differentiation pattern of $\mathrm{T}$ cells in the allograft during TCMR may be different from that 
observed in peripheral blood. Therefore, we used tubular epithelial cells as key targets of the allo-reactive $\mathrm{T}$ cells. $[39,40]$ After contact with HRPTEpiFCs, a significant proliferation of the $\mathrm{CD} 4^{+} \mathrm{T}$ cells was detected. The added of Tac alone did not suppress the proliferation of $\mathrm{CD}^{+}{ }^{+} \mathrm{T}$ cells. However, the combination of Resv to Tac significantly diminished the proliferation of $\mathrm{CD} 4^{+} \mathrm{T}$ cells compared to activated $\mathrm{CD}^{+}{ }^{+} \mathrm{T}$ cell conditions or Tac alone. Unfortunately, we did not inspect the subset of proliferating $\mathrm{CD}_{4}^{+} \mathrm{T}$ cells. We cultured isolated PBMCs under Th17 polarizing conditions before PKH-labeling, hence the proportion of Th17 cells in PKH-labeled T cells may be higher than that of un-stimulated PBMCs. Therefore, it is possible that Tac alone may not be effective in suppressing the $\mathrm{PKH}^{-} \mathrm{CD}_{4}^{+} \mathrm{T}$ cells as demonstrated in our in vitro study using PBMCs. Another possible reason is that since almost all $\mathrm{T}$-cell subsets are actively proliferated after contact with HRPTEpiCs, including an increase in the memory $\mathrm{T}$ cell subset, this may result in resistance to Tac-based immunosuppresison in the in vitro study. [41] More effective immune suppression by the combination of Resv to Tac may result in the suppression of the proliferating memory $\mathrm{T}$ cell subtypes. However, further investigation may be required to clarify this issue.

Recent studies have shown that the mTOR/AMPK pathway plays an essential role in the differentiation of $\mathrm{T}$ cells. [42] mTOR is activated upon stimulation of the T cell receptor, and it plays an important role in the regulation of Th17 differentiation. [21] In addition, the activation of AMP-activated protein kinase (AMPK) can diminish mTOR signaling through the phosphorylation of TSC2 and RAPTOR, which is a crucial component of mTORC1. [43] Based on the above findings, we investigated whether the AMPK/mTOR pathway is involved in the suppressive effects of Resv on T cells using the Jurkat cell line. In our study, Tac alone shows an insignificant effect on the phosphorylation of AMPK or mTOR pathway. However, in the Resv condition, a significant increase in the phosphorylation of AMPK and a reciprocal decrease in the phosphorylation of mTOR was detected in a dose-dependent manner. This result suggests that AMPK/ mTOR signaling may be involved in the suppressive effects of Resv on $\mathrm{CD} 4^{+} \mathrm{T}$ cell proliferation. [19, 44, 45]

Finally, we intended to investigate the immune modulating effects of Resv using a well-established skin allograft mouse model. [46] The use of Tac significantly improved skin allograft survival when compared to the control group, and this result is similar to the survival rate of previous skin allograft mouse models. [47] The combination of Resv to Tac further prolonged survival duration of skin allograft. In an ex vivo study using mice spleen cells, the proportion of Th1 cells were significantly decreased in the group with Tac alone, but Th17 was not suppressed in this group. However, the combination of Resv to Tac resulted in a significant decrease in the proportion of Th17 cells, which is consistent with our in vitro studies. Many studies have demonstrated that acute rejection of allografts is associated with an increase in Th1 reactivity, with high levels of IL-2, IFN- $\gamma$ mRNA and protein detected within the grafts. [46] Also, blocking the IL-17 function in a rat cardiac allograft transplantation model produced a significant increase in graft survival. The same group later showed that IL-17 antagonism inhibited rejection in a murine aortic transplantation model. [48] Therefore, it is possible that effective regulation of both Th1 and Th17 through the combination of Resv to Tac may result in better allograft survival.

A limitation of our experiment is that the experimental concentration of Resv is higher than a realistic dose. Hence, we could not suggest an appropriate dose of Resv that may show immunologic benefits in clinical practice. However, Resv contained in various healthy foods has shown significant health benefits in the general population $[49,50]$. Therefore it is possible that an ordinary dose of Resv taken in such healthy foods may produce the immunologic benefits shown in this study. Second, another mechanism of Resv can be associated with the effective suppression of Th17 in this study. For example, Resv can inhibit CYP enzyme involved in the Tac metabolism. It may result in the increased immune suppressive effect of Tac. [51] However, further translational or clinical research may be required to clarify this issue.

\section{Conclusions}

We found that the combination of Resv to Tac resulted in significant suppressive effects on the differentiation of Th17 cells that are involved in the development of allograft rejection in an in vitro and in vivo study. Therefore, we suggest that Resv can be used as a therapeutic agent to complement the effects of Tac-based immunosuppression in organ transplantation.

\section{Abbreviations \\ AMPK: AMP-activated protein kinase; CNIs: calcineurin inhibitors; FCS: fetal calf serum; FBS: fetal bovine serum; H\&E: hematoxylin-eosin; HRPTEpiCs: human renal proximal tubular epithelial cells; mTOR: mammalian target of rapamycin; PBMCs: peripheral blood mononuclear cells; Resv: Resveratrol; SOT: solid organ transplantation; TAC: tacrolimus; Th17: T helper 17 cells}

\section{Acknowledgements \\ The authors would like to thank all of the colleagues who contributed to this study.}

\section{Funding}

This research was supported by a grant of the Korean Health Technology R\&D Project, Ministry of Health \& Welfare, Republic of Korea (HI13C1232), and the Korean Health Technology R\&D Project, Ministry for Health \& Welfare, Republic of Korea (HI14C3417). 


\section{Availability of data and materials}

All data and analyses in the current study are available from the corresponding author upon reasonable request.

\section{Authors' contributions}

DKC performed in vivo and in vitro study, interpreted data and prepared the manuscript. KBM and KKW helped in vivo study. CBH work together in vitro study. YCW directed experiments and prepared the manuscript. All authors read and approved the final manuscript.

\section{Ethics approval and consent to participate}

The Institutional Review Board of Seoul St. Mary's Hospital (KC14TISI0242) approved the experimental protocol of this study. Furthermore, a written consent was sorted from volunteers.

\section{Consent for publication}

Not applicable.

\section{Competing interests}

The authors declare that they have no competing interests.

\section{Publisher's Note}

Springer Nature remains neutral with regard to jurisdictional claims in published maps and institutional affiliations.

\section{Author details}

${ }^{1}$ Convergent Research Consortium for Immunologic disease, St. Mary's Hospital, The Catholic University of Korea, Seoul, South Korea. ${ }^{2}$ Transplant research center, St. Mary's Hospital, The Catholic University of Korea, Seoul, South Korea. ${ }^{3}$ Department of Internal Medicine, College of Medicine, Seoul St. Mary's Hospital, The Catholic University of Korea, Seoul, South Korea.

Received: 31 August 2017 Accepted: 25 February 2019

Published online: 04 March 2019

\section{References}

1. Calvo-Turrubiartes M, Romano-Moreno S, Garcia-Hernandez M, ChevaileRamos JA, Layseca-Espinosa E, Gonzalez-Amaro R, et al. Quantitative analysis of regulatory $T$ cells in kidney graft recipients: a relationship with calcineurin inhibitor level. Transpl Immunol. 2009;21:43-9.

2. Loong CC, Lin CY, Lui WY. Expression of interleukin-17 as a predictive parameter in acute renal allograft rejection. Transplant Proc. 2000;32:1773.

3. Hsieh HG, Loong CC, Lui WY, Chen A, Lin CY. IL-17 expression as a possible predictive parameter for subclinical renal allograft rejection. Transpl Int. 2001:14:287-98

4. Mitchell P, Afzali B, Lombardi G, Lechler RI. The T helper 17-regulatory T cell axis in transplant rejection and tolerance. Curr Opin Organ Transplant. 2009; 14:326-31.

5. Crispim JC, Grespan R, Martelli-Palomino G, Rassi DM, Costa RS, Saber LT, et al. Interleukin-17 and kidney allograft outcome. Transplant Proc. 2009;41: 1562-4.

6. Chung B, Yang C, Cho M. Clinical significance of Th17 cells in kidney transplantation. Korean J Intern Med. 2018

7. Halloran PF. Immunosuppressive drugs for kidney transplantation. N Engl Med. 2004;351:2715-29.

8. Deteix C, Attuil-Audenis V, Duthey A, Patey N, McGregor B, Dubois V, et al. Intragraft Th17 infiltrate promotes lymphoid neogenesis and hastens clinical chronic rejection. J Immunol. 2010;184:5344-51.

9. Chung BH, Oh HJ, Piao SG, Hwang HS, Sun IO, Choi SR, et al. Clinical significance of the ratio between FOXP3 positive regulatory $T$ cell and interleukin-17 secreting cell in renal allograft biopsies with acute T-cellmediated rejection. Immunology. 2012;136:344-51.

10. Chung BH, Oh HJ, Piao SG, Sun IO, Kang SH, Choi SR, et al. Higher infiltration by Th17 cells compared with regulatory $T$ cells is associated with severe acute T-cell-mediated graft rejection. Exp Mol Med. 2011;43:630-7.

11. Warrens AN. Pharmacological control of the immune response in renal transplantation. BJU Int. 2002;90:784-91.

12. Joean $O$, Hueber $A$, Feller F, Jirmo AC, Lochner $M$, Dittrich $A-M$, et al. Suppression of Th17-polarized airway inflammation by rapamycin. Sci Rep. 2017;7:15336.
13. Yago T, Nanke Y, Kawamoto M, Yamanaka H, Kotake S. Tacrolimus potently inhibits human osteoclastogenesis induced by IL-17 from human monocytes alone and suppresses human Th17 differentiation. Cytokine. 2012;59:252-7.

14. Jain A, Doppalapudi S, Domb AJ, Khan W. Tacrolimus and curcumin Coloaded liposphere gel: synergistic combination towards management of psoriasis. J Control Release. 2016;243:132-45.

15. Chung BH, Kim KW, Kim BM, Piao SG, Lim SW, Choi BS, et al. Dysregulation of Th17 cells during the early post-transplant period in patients under calcineurin inhibitor based immunosuppression. PLoS One. 2012;7:e42011.

16. Kim KW, Chung BH, Kim BM, Cho ML, Yang CW. The effect of mammalian target of rapamycin inhibition on $\mathrm{T}$ helper type 17 and regulatory $\mathrm{T}$ cell differentiation in vitro and in vivo in kidney transplant recipients. Immunology. 2015;144:68-78.

17. Szkudelski T, Szkudelska K. Resveratrol and diabetes: from animal to human studies. Biochim Biophys Acta. 1852;2015:1145-54.

18. Gwinn DM, Shackelford DB, Egan DF, Mihaylova MM, Mery A, Vasquez DS, et al. AMPK phosphorylation of raptor mediates a metabolic checkpoint. Mol Cell. 2008;30:214-26.

19. Widlund AL, Baur JA, Vang O. mTOR: more targets of resveratrol? Expert Rev Mol Med. 2013;15:e10.

20. Kim M, Lim J, Youn H, Hong Y, Yang K, Park H, et al. Resveratrol prevents renal lipotoxicity and inhibits mesangial cell glucotoxicity in a manner dependent on the AMPK-SIRT1-PGC1a axis in $\mathrm{db} / \mathrm{db}$ mice. Diabetologia. 2013;56:204-17.

21. Delgoffe GM, Kole TP, Zheng Y, Zarek PE, Matthews KL, Xiao B, et al. The mTOR kinase differentially regulates effector and regulatory $T$ cell lineage commitment. Immunity. 2009;30:832-44.

22. Alvarez-Lara MA, Carracedo J, Ramírez R, Martín-Malo A, Rodríguez M, Madueño JA, et al. The imbalance in the ratio of Th1 and Th2 helper lymphocytes in uraemia is mediated by an increased apoptosis of Th 1 subset. Nephrol Dial Transplant. 2004;19:3084-90.

23. Chung BH, Kim B-M, Doh KC, Cho M-L, Kim KW, Yang CW. Protective effect of 1a, 25-dihydroxyvitamin D3 on effector CD4+ T cell induced injury in human renal proximal tubular epithelial cells. PLoS One. 2017;12:e0172536.

24. de Haij S, Woltman AM, Trouw LA, Bakker AC, Kamerling SW, van der Kooij SW, et al. Renal tubular epithelial cells modulate T-cell responses via ICOS-L and B7-H1. Kidney Int. 2005;68:2091-102.

25. McFarland HI, Rosenberg AS. Skin allograft rejection. Curr Protoc Immunol. 2009;84(4):1-4 13.

26. Schwoebel F, Barsig J, Wendel A, Hamacher J. Quantitative assessment of mouse skin transplant rejection using digital photography. Lab Anim. 2005;39:209-14.

27. Chung BH, Kim B-M, Doh KC, Min J-W, Cho M-L, Kim KW, et al. Suppressive effect of 1 [alpha], 25-Dihydroxyvitamin D3 on Th17-immune responses in kidney transplant recipients with tacrolimus-based immunosuppression. Transplantation. 2017.

28. Sakuma S, Higashi Y, Sato N, Sasakawa T, Sengoku T, Ohkubo Y, et al. Tacrolimus suppressed the production of cytokines involved in atopic dermatitis by direct stimulation of human PBMC system.(comparison with steroids). Int Immunopharmacol. 2001;1:1219-26.

29. Tocci MJ, Matkovich DA, Collier KA, Kwok P, Dumont F, Lin S, et al. The immunosuppressant FK506 selectively inhibits expression of early T cell activation genes. J Immunol. 1989;143:718-26.

30. Andersson J, Nagy S, Groth C, Andersson U. Effects of FK506 and cyclosporin a on cytokine production studied in vitro at a single-cell level. Immunology. 1992;75:136.

31. Abadja F, Sarraj B, Ansari MJ. Significance of Th17 immunity in transplantation. Curr Opin Organ Transplant. 2012;17:8.

32. Abadja F, Atemkeng S, Alamartine E, Berthoux F, Mariat C. Impact of mycophenolic acid and tacrolimus on Th17-related immune response. Transplantation. 2011:92:396-403.

33. Rachoń D, Rimoldi G, Wuttke W. In vitro effects of genistein and resveratrol on the production of interferon- $\gamma$ (IFN $\gamma)$ and interleukin-10 (IL-10) by stimulated murine splenocytes. Phytomedicine. 2006;13:419-24.

34. X-d L, Wang H-d, S-j X, Skog S, Sun J. Effects of resveratrol on the expression and DNA methylation of cytokine genes in diabetic rat aortas. Arch Immunol Ther Exp. 2014:62:329-40.

35. Petro TM. Regulatory role of resveratrol on Th17 in autoimmune disease. Int Immunopharmacol. 2011;11:310-8.

36. Yao J, Wei C, Wang J-Y, Zhang R, Li Y-X, Wang L-S. Effect of resveratrol on Treg/Th17 signaling and ulcerative colitis treatment in mice. World J Gastroenterol. 2015;21:6572. 
37. Wenbin Z, Guojun G. Resveratrol ameliorates diabetes-induced renal damage through regulating the expression of TGF- $\beta 1$, collagen IV and Th17/Treg-related cytokines in rats. West Indian Med J. 2014;63:20.

38. Van Parijs L, Refaeli Y, Lord JD, Nelson BH, Abbas AK, Baltimore D. RETRACTED: uncoupling $\mathrm{IL}-2$ signals that regulate $\mathrm{T}$ cell proliferation, survival, and Fasmediated activation-induced cell death. Immunity. 1999;11:281-8.

39. Van Kooten C, Boonstra JG, Paape ME, Fossiez F, Banchereau J, Lebecque S, et al. Interleukin-17 activates human renal epithelial cells in vitro and is expressed during renal allograft rejection. J Am Soc Nephrol. 1998;9:1526-34.

40. Woltman AM, De Haij S, Boonstra JG, Gobin SJ, Daha MR, Van Kooten C. Interleukin-17 and CD40-ligand synergistically enhance cytokine and chemokine production by renal epithelial cells. J Am Soc Nephrol. 2000;11: 2044-55.

41. Demmers MW, Baan CC, Janssen M, Litjens NH, ljzermans JN, Betjes MG, et al. Substantial proliferation of human renal tubular epithelial cell-reactive CD4+CD28null memory T cells, which is resistant to tacrolimus and everolimus. Transplantation. 2014;97:47-55.

42. Chi H. Regulation and function of mTOR signalling in T cell fate decisions. Nat Rev Immunol. 2012;12:325-38.

43. Inoki K, Kim J, Guan K-L. AMPK and mTOR in cellular energy homeostasis and drug targets. Annu Rev Pharmacol Toxicol. 2012;52:381-400.

44. Dasgupta B, Milbrandt J. Resveratrol stimulates AMP kinase activity in neurons. Proc Natl Acad Sci U S A. 2007;104:7217-22.

45. Vingtdeux V, Giliberto L, Zhao H, Chandakkar P, Wu Q, Simon JE, et al. AMPactivated protein kinase signaling activation by resveratrol modulates amyloid- $\beta$ peptide metabolism. J Biol Chem. 2010;285:9100-13.

46. Rosenberg AS, Singer A. Cellular basis of skin allograft rejection: an in vivo model of immune-mediated tissue destruction. Annu Rev Immunol. 1992; 10:333-60.

47. Lopes C, Gallo A, Palma P, Cury P, Bueno V. Skin allograft survival and analysis of renal parameters after FTY720+ tacrolimus treatment in mice. Transplant Proc: Elsevier; 2008. p. 856-60.

48. Tang J-L, Subbotin VM, Antonysamy MA, Troutt AB, Rao AS, Thomson AW. Interleukin-17 antagonism inhibits acute but not chronic vascular rejection. Transplantation. 2001;72:348-50.

49. Marques FZ, Markus MA, Morris BJ. Resveratrol: cellular actions of a potent natural chemical that confers a diversity of health benefits. Int J Biochem Cell Biol. 2009:41:2125-8.

50. Burns J, Yokota T, Ashihara H, Lean ME, Crozier A. Plant foods and herbal sources of resveratrol. J Agric Food Chem. 2002;50:3337-40.

51. Jang GR, Harris RZ. Drug interactions involving ethanol and alcoholic beverages. Expert Opin Drug Metab Toxicol. 2007;3:719-31.

Ready to submit your research? Choose BMC and benefit from:

- fast, convenient online submission

- thorough peer review by experienced researchers in your field

- rapid publication on acceptance

- support for research data, including large and complex data types

- gold Open Access which fosters wider collaboration and increased citations

- maximum visibility for your research: over $100 \mathrm{M}$ website views per year

At BMC, research is always in progress.

Learn more biomedcentral.com/submissions 